\title{
Chromosomal control of pig populations in France: 2002-2006 survey
}

\author{
Alain DuCos*, Hélène-Marie BERLAND, Nathalie BONNET, \\ Anne CAlgaro, Sébastien BILlouX, Nicolas MARY, \\ Amélie GARnIER-BonNET, Roland DARRÉ, Alain PINTON
}

UMR INRA-ENVT 444 Génétique cellulaire, École nationale vétérinaire de Toulouse, 23 chemin des Capelles - BP 87614, 31076 Toulouse cedex 3, France

(Received 29 January 2007; accepted 26 February 2007)

\begin{abstract}
The chromosomal control of pig populations has been widely developed in France over the last ten years. By December 31st, 2006, 13765 individuals had been karyotyped in our laboratory, $62 \%$ of these since 2002 . Ninety percent were young purebred boars controlled before service in artificial insemination centres, and 3\% were hypoprolific boars. So far, 102 constitutional structural chromosomal rearrangements (67 since 2002) have been described. Fiftysix were reciprocal translocations and 8 peri- or paracentric inversions. For the first time since the beginning of the programme and after more than 11000 pigs had been karyotyped, one Robertsonian translocation was identified in 2005 and two others in 2006. The estimated prevalence of balanced structural chromosomal rearrangements in a sample of more than 7700 young boars controlled before service was $0.47 \%$. Twenty-one of the 67 rearrangements described since 2002 were identified in hypoprolific boars. All were reciprocal translocations. Twelve mosaics $(\mathrm{XX} / \mathrm{XY}$ in 11 individuals, $\mathrm{XY} / \mathrm{XXY}$ in one individual) were also diagnosed. Two corresponded to hypoprolific boars, and three to intersexed animals. The results presented in this communication would justify an intensification of the chromosomal control of French and, on a broader scale, European and North-American pig populations.
\end{abstract}

chromosome / translocation / inversion / pig / reproductive performance

\section{INTRODUCTION}

Numerical and/or structural chromosomal rearrangements can be responsible for various clinical disorders. Some rearrangements are acquired whereas others are constitutional. The former generally appear late in life, and only affect one or a few cell lines. They may be involved in the development of certain cancers [3]. In contrast, a constitutional chromosomal rearrangement is

\footnotetext{
*Corresponding author: a.ducos@envt.fr
} 
present from conception onwards and, except for cases of mosaïcism, affects all the cells of the organism in the same way. It can be inherited from one of the parents, or appear de novo in the individual. In humans, by far the best known species from a cytogenetic point of view, constitutional chromosomal rearrangements affect $8.3 \%$ of the newborn [13]. About half of these (4.3\%o) are balanced structural rearrangements (neither gain nor loss of chromosomal material, e.g. reciprocal translocations, inversions...). Such rearrangements are responsible for congenital malformations, mental retardation and reproductive failures.

Due to the major medical stakes, the development of human cytogenetics was of great importance during the 20th century. Hundreds of human cytogenetic laboratories were created throughout the world. Animal cytogenetics developed relatively late in comparison and much more slowly. The number of laboratories significantly involved in clinical cytogenetic activities in farm animals is very limited. The number of cytogenetic investigations carried out in cases of congenital malformations, for instance, is relatively low in livestock species, whereas such investigations are systematic in humans. However, the impact of some constitutional structural chromosomal rearrangements on the reproductive function of carrier animals or of their mates has been documented for a long time and on many occasions in several livestock species [10,22]. In pigs, the most frequently reported chromosomal rearrangements are reciprocal translocations. Sixty-eight were known in 1997 [5]. Many more have been described since then [7]. An individual heterozygote for a constitutional reciprocal translocation will generally produce a high proportion of genetically unbalanced gametes [19] leading to an early mortality of the embryos produced by this animal [12]. For a boar, this generally results in a considerable decrease in the average litter size of its mates: from $-10 \%$ to $-100 \%$ depending on the translocation, $-40 \%$ on average $[4,16,21]$. Such chromosomal rearrangements can therefore lead to major economic losses for professional organisations if carrier animals produce a large number of litters, as is generally the case for boars used in artificial insemination centres. In addition, 50\% of the live-born offspring of a carrier animal will themselves carry the rearrangement. In the absence of controls, some of these carrier offspring may in turn be used as reproducers resulting in widespread distribution of the rearrangement in the population. In several countries this possibility has justified the instigation of chromosomal control programmes, mainly in hypoprolific boars (a posteriori screening programmes [12]) and more recently in young boars intended for large scale use in artificial insemination centres (systematic a priori control programmes). 
At present, in France, almost all the chromosomal analyses in pigs are carried out at just one laboratory located at the National Veterinary School of Toulouse. The volume of activity has been growing almost exponentially over the past 10 years (about 2000 controls per year now) and is unique in the world. An initial survey of the activities was produced in 2002 for a national (French) professional symposium [7]. The aim of this current paper was to present an up to date survey of the chromosomal control programme being carried out in France in the pig species.

\section{MATERIAL AND METHODS}

\subsection{Animals controlled}

About $90 \%$ of the requests for analyses received in our laboratory during the 2002-2006 period (1500 to 2000 per year) concerned 6 to 10 month-old purebred boars waiting for an approval for use in artificial insemination (AI) centres (animals controlled before service). Most of them were intended to sire sows in selection and/or multiplication herds. Male as well as female parental lines were concerned. All these boars had already gone through the selection procedures regarding their estimated breeding values and various morphological parameters, and presented no observable defect. Eighty-eight percent of these analyses were carried out for three major French pig breeding organisations.

At the same time (2002-2006), 20 to 70 hypoprolific boars were controlled annually. This represented $3 \%$ of the total number of analyses carried out in the laboratory during this period. About half of these hypoprolific boars were detected at the laboratory level by making use of centralised national databases $[11,25]$. The other half was directly detected by the breeding organisations. This was particularly the case for selection companies in other European countries (The Netherlands, Belgium, Germany, Spain...) from which a growing number of analyses have been requested over the last two years.

Finally, $7 \%$ of the analyses carried out in our laboratory during the 2002-2006 period concerned animals belonging to the families of carrier individuals: parents, (half)sibs, offspring...

\subsection{Analytical methods}

The technical procedures used to obtain the karyotypes were similar to those employed in human cytogenetic laboratories. Standard banding protocols were 
used for all the analyses: systematically GTG banding, complementary RBG banding in some cases being particularly difficult to interpret (see for instance [6] for details). The number of chromosomes in at least 10 metaphases was determined for each individual. Whenever this number differed from the expected one $(2 \mathrm{n}=38)$ in one or more cells, complementary counts were carried out. At least three complete karyotypes were established for each individual. The analyses were carried out using the Genus ${ }^{\circledR}$ software (Applied Imaging).

For some particular rearrangements, the hypotheses concerning the chromosomes involved and/or the location of breakpoints on the chromosomes were verified using molecular cytogenetic techniques: chromosome painting (probes generated using flow-sorted or microdissected chromosomes $[8,15,18]$ ), fluorescent in situ hybridisation using probes generated from BAC clones [17].

\section{RESULTS}

By December 31st, 2006, 13765 pigs had been karyotyped in our laboratory, with a total of $8548(62 \%)$ since 2002. As shown in Figure 1, the number of analyses carried out over the past 10 years has greatly increased. During the 2002-2006 period considered in this survey, between 1500 and 2000 pigs were karyotyped in our laboratory each year, i.e. an average of 30 to 40 per week.

In total, 102 original structural chromosomal rearrangements have been identified in the pig species in our laboratory (December 31st, 2006 statistics), including 67 during the 2002-2006 period (Tab. I, App. I - the complete list of chromosomal rearrangements identified before 2002 was published earlier [7]).

The number of new structural chromosomal rearrangements identified each year during that period varied from 9 to 16. Apart from the analyses in families of carrier animals, all the structural chromosomal rearrangements identified in our laboratory (listed in App. I) were new and had not been described previously. Fifty-six of the 67 structural rearrangements identified during the 2002-2006 period (i.e. 84\%) were reciprocal translocations. Eight were perior paracentric inversions. In 2005 a Robertsonian translocation was identified in a boar for the first time in our laboratory after more than 11000 individuals had been controlled. It involved chromosomes 14 and 15. Two other Robertsonian translocations have been identified since then. These involve chromosomes 14 and 17, and 13 and 17, respectively (Fig. 2).

Other new structural chromosomal rearrangements were characterised during the 2002-2006 period. A Y-autosome translocation was identified for the first time in the pig species: $t(Y ; 14)(q 10 ; q 11)-$ Figure 3. The young Duroc 


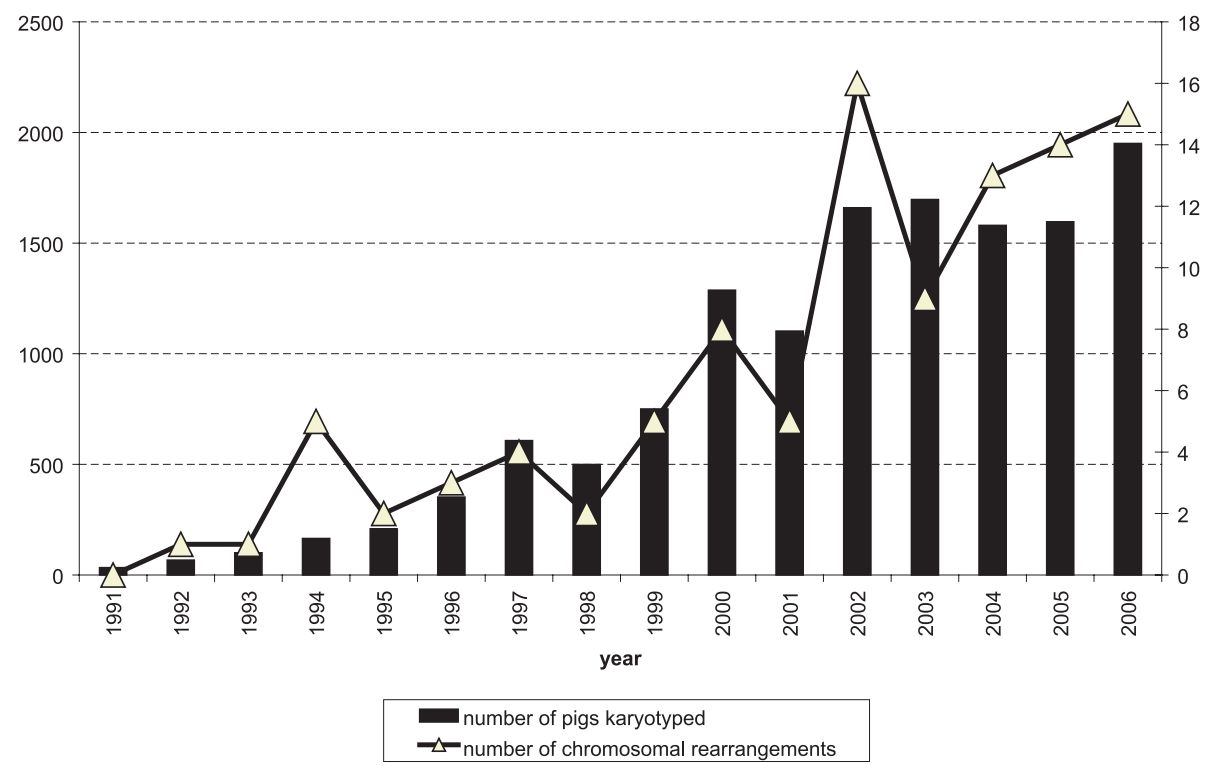

Figure 1. Evolution of the annual number of animals karyotyped in the laboratory, and of the number of structural chromosomal rearrangements identified.

Table I. Distribution of the constitutional structural chromosomal rearrangements identified in the laboratory during the 2002-2006 period.

\begin{tabular}{|c|c|c|c|c|c|c|c|}
\hline & \multicolumn{3}{|c|}{ Reciprocal translocations } & \multicolumn{2}{c|}{ Inversions } & $\begin{array}{c}\text { Robertsonian } \\
\text { translocations }\end{array}$ & Total \\
\hline & $\begin{array}{c}\text { Hypoprolific } \\
\text { boars }\end{array}$ & $\begin{array}{c}\text { Routine } \\
\text { boars }^{\text {a }}\end{array}$ & Females & $\begin{array}{c}\text { Routine } \\
\text { boars }\end{array}$ & Females & $\begin{array}{c}\text { Routine } \\
\text { boars }\end{array}$ & \\
\hline 2002 & 4 & 8 & 1 & 3 & & & 16 \\
\hline 2003 & 4 & 5 & & & & & 9 \\
\hline 2004 & 4 & 4 & 3 & 1 & 1 & & 13 \\
\hline 2005 & 4 & 6 & 1 & 2 & & 1 & 14 \\
\hline 2006 & 5 & 5 & 2 & 1 & & 2 & 15 \\
\hline Total & 21 & 28 & 7 & 7 & 1 & 3 & 67 \\
\hline
\end{tabular}

${ }^{a}$ Young boars controlled before service in artificial insemination centres.

boar carrying this rearrangement (7 months-old at the time of analysis) was unable to produce semen. The histological analyses carried out on testicular biopsies of this animal showed an arrest of spermatogenesis at the spermatocyte stage.

For the first time, the simultaneous presence of two balanced structural chromosomal rearrangements was identified in two individuals, in 2005. One 


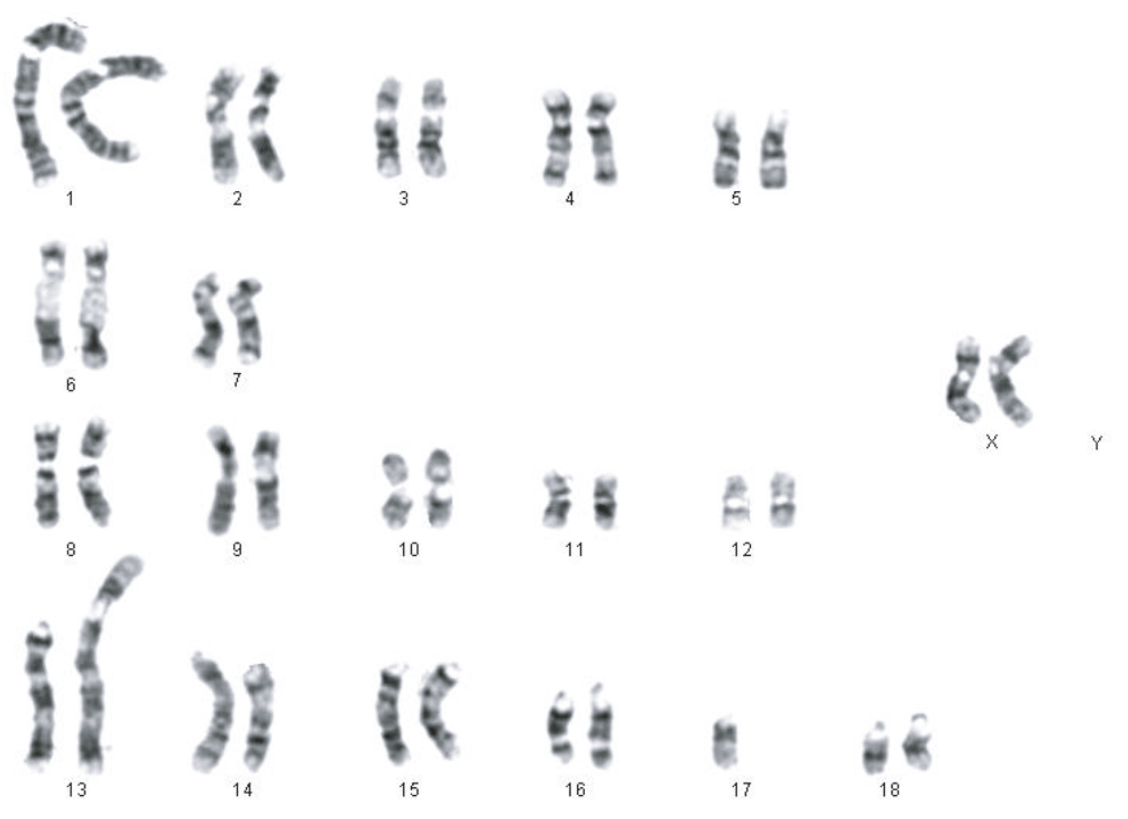

Figure 2. GTG-banding karyotype of a gilt carrier of the 13/17 Robertsonian translocation.

NB: The rearrangement was initially identified in a boar; daughters were produced for experimental purposes.

carried a pericentric inversion of chromosome 2 as well as a reciprocal translocation involving chromosomes 13 and 14. The other animal carried two reciprocal translocations simultaneously, one involving chromosomes 6 and 8, the other involving chromosomes 10 and 18 (App. I). This latter animal, a boar of Pietrain breed, produced semen and the semen parameters were normal. The conclusion of the spermogram carried out at the LNCR laboratory (Laboratoire national de contrôle des reproducteurs) was "favourable". Ten purebred Meishan sows from an experimental herd belonging to INRA were repeatedly inseminated with semen from this boar. No gestation could be obtained.

As indicated in Table I, 38 of the 67 rearrangements identified during 20022006 (i.e. 57\%) concerned young boars controlled before service in AI centres (36 boars, two carrying two rearrangements simultaneously). During this period, 7700 such boars were controlled. Thus the prevalence of balanced constitutional structural chromosomal rearrangements in this sample was $0.47 \%$ (36/7700). 


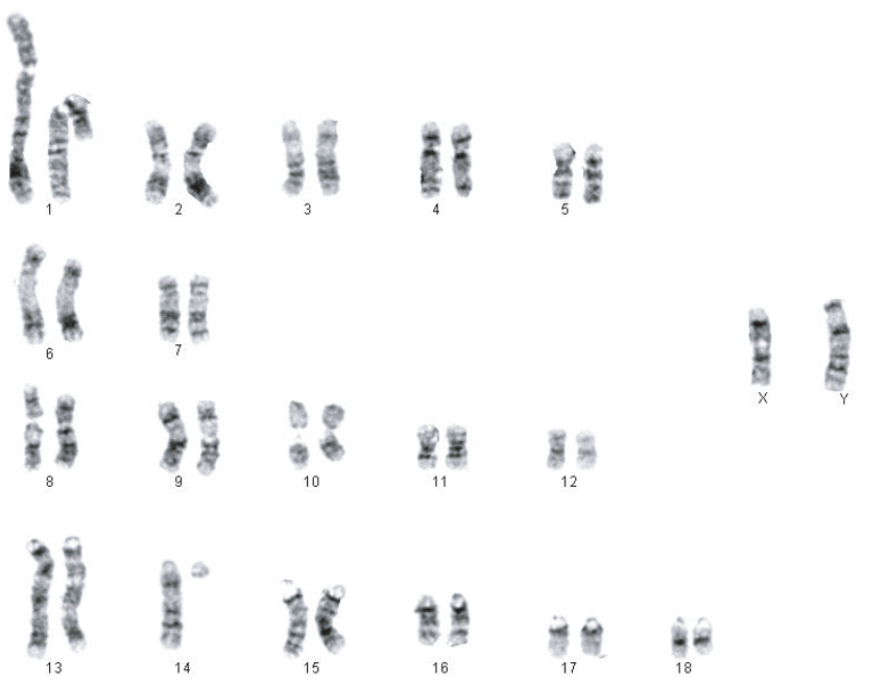

(a)

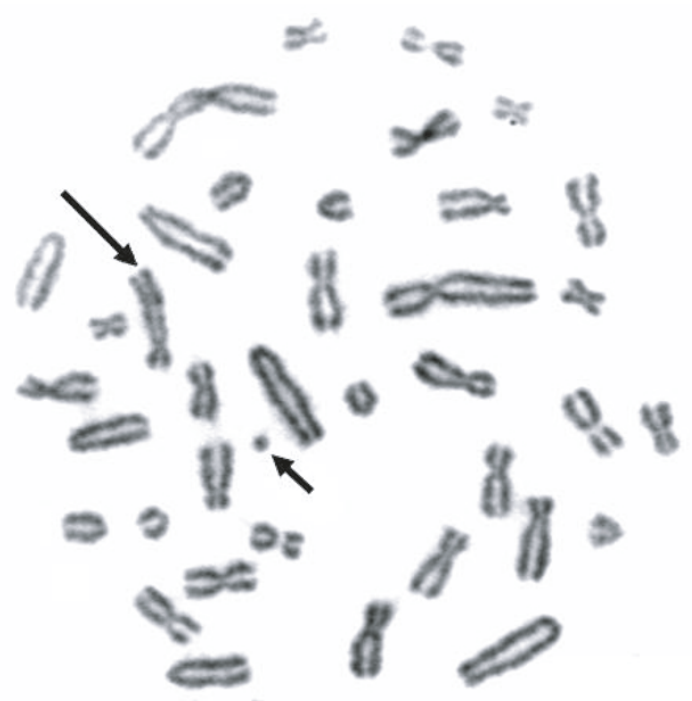

(b)

Figure 3. (a) GTG-banding karyotype of a boar carrier of the t(Y;14)(q10;q11) reciprocal translocation. (b) Metaphase spread of the boar conventionally stained with Giemsa.

Large arrow: derivative chromosome Y.

Small arrow: derivative chromosome 14. 
Twenty-one of the 67 structural chromosomal rearrangements were identified in hypoprolific boars. All were reciprocal translocations. In most cases (19/21), the hypoprolific boars were directly detected by the breeding organisations. Reproductive data were available in only three cases. The boar carrying the $\mathrm{t}(12 ; 14)(\mathrm{q} 13 ; \mathrm{q} 15)$ reciprocal translocation sired 57 litters with an average size of 6.7 piglets (total number born). This was 39\% lower than the average litter size sired by the other contemporary boars in the herd. The boar carrying the $t(4 ; 5)(\mathrm{p} 13 ; \mathrm{q} 21)$ translocation sired 74 piglets in 11 litters $(6.7$ piglets per litter also). This boar was considered as hypoprolific by the breeder but the reproductive data for the other contemporary boars were not supplied. The third boar, carrying the $\mathrm{t}(7 ; 14)(\mathrm{q} 26 ; \mathrm{q} 25)$ translocation, sired 33 litters with an average size of 7.7 piglets. Again, the reproductive data of the other contemporary boars were not given to us. One of the reciprocal translocations, $\mathrm{t}(3 ; 16)(\mathrm{q} 23 ; \mathrm{q} 22)$, was detected in a hypoprolific boar which also generated dozens of malformed piglets (cleft palate). The cytogenetical investigations carried out in the offspring of the boar revealed an unbalanced karyotype in all malformed piglets (partial trisomy of chromosome 3 as well as partial monosomy of chromosome 16), and a balanced karyotype (normal, or carrier of the same translocation as in the boar) in the phenotypically normal piglets. The unbalanced karyotype of the malformed piglets was the result of an adjacent-I segregation in the sire [9].

Eight of the 67 rearrangements (seven reciprocal translocations and one inversion) were identified in females. Four of these females belonged to a sinoEuropean synthetic line in the process of creation (App. I). Systematic controls were carried out on all reproducers in this population in which several rearrangements were segregating. One female was controlled because of her low prolificacy. Two others were controlled in connection with familial eradication programmes being carried out for different rearrangements. The fourth, which was of Meishan breed, was controlled as part of specific experimentation managed by our laboratory.

Apart from the above structural chromosomal rearrangements, other kinds of rearrangements called "mosaics" were identified. Eleven cases of XX/XY mosaicism were detected. The estimated proportion of XY cells in these mosaics ranged from $15 \%$ to $99 \%$. Two of these 11 cases corresponded to hypoprolific boars (reproductive data not supplied by the breeders), four were young purebred boars controlled before service in AI centres, and three were declared as "intersexed" by the breeders. One case of XY/XXY mosaicism (97\% of XXY cells) was also diagnosed in a French Landrace boar. Histological analyses were carried out on bilateral testicular biopsies. They revealed 
strong bilateral seminiferous hypoplasia associated with severe interstitial proliferation of the Leydig cells and lack of maturation of the germinal cells.

\section{DISCUSSION}

The diagnostic activity developed in our laboratory, with more than 1500 animals having been controlled annually since 2002 and about 14000 pigs karyotyped up to now, is unique in the world. Moreover, the descriptions of more than one hundred new abnormalities have greatly contributed to the discovery of chromosomal rearrangements in pigs (so far, fewer than 100 other cases have been published worldwide). Some kinds of rearrangements have never been reported before (Y-autosome translocation, two simultaneous structural rearrangements in the same individual). The number of analyses has increased dramatically over the past ten years. Most recently, the greatest increase has corresponded to requests from other European countries (mainly The Netherlands). This demonstrates the desire of the corresponding selection companies to implement systematic chromosomal control programmes, as already achieved by their French competitors several years ago. During 2006, 1950 pigs were karyotyped in our laboratory. This number corresponds to the maximum capacity of the laboratory in its current configuration. The future development of chromosome control activities worldwide, clearly consistent with requests expressed by several professional organisations, would therefore benefit from a strong involvement of other European and North American laboratories.

The number of new rearrangements identified in 2002 could appear as abnormally important (Fig. 1). But this figure can partly be explained by the relatively low number of rearrangements identified in 2001 and 2003. On the contrary, the total number of analyses also strongly increased between 2001 and 2002 because of the involvement of new breeding companies in the control programme. This resulted logically in a larger number of rearrangements identified during this year. Lastly, new populations, and more precisely male selected lines (including Piétrain populations) were newly controlled from 2002 onwards. Such populations had never been subjected to large scale cytogenetic investigations before. This could also partly explain the fact that an important number of rearrangements were identified during this particular year.

Thirty-eight of the 67 structural chromosomal rearrangements described were carried by young purebred boars waiting for service in AI centres and intended for use in selection and multiplication herds. Massive diffusion of these chromosomal abnormalities was avoided by culling these animals when 
the rearrangements had been identified. The considerable economic losses to the breeding organisations that would have otherwise occurred would have far exceeded the global cost of the control procedures [4,23].

The prevalence of balanced structural constitutional chromosomal rearrangements in pigs, based on the most recent results obtained in the laboratory, is $0.47 \%$. That is to say, one young boar out of two hundred is likely to carry a structural chromosomal rearrangement. This confirmed the estimate obtained in 2002 from a much smaller sample [8]. It is also consistent with the estimated value in humans at birth (0.43\% [13]). However, the estimation in pigs concerned animals that had reached the age of puberty. The estimated prevalence at birth would have been higher than the value of 0.47 indicated here. To the best of our knowledge, the pig (Sus scrofa domestica L.) is the only animal species other than Man for which an accurate estimate of the prevalence of structural chromosomal rearrangements is available.

Since 2002, 21 chromosomal rearrangements have been identified in hypoprolific boars. The fact that all were reciprocal translocations could lead us to think that the other kinds of rearrangements (peri- and paracentric inversions, Robertsonian translocations) have no effect on reproduction. However, there has not been enough time nor experimental work carried out on these kinds of rearrangements in pigs to assess their effects accurately (the first inversion in pigs was identified only 10 years ago [14]). On the contrary, the results obtained in Man clearly show that an individual heterozygote for an inversion or for a Robertsonian translocation might produce a non negligible proportion of unbalanced gametes ( $0 \%$ to $37.4 \%$ depending on the inversion [1]; $3 \%$ to $60 \%$ depending on the Robertsonian translocation [24]), even though these values are globally lower than the estimates for reciprocal translocations (19\% to $81 \%$ depending on the translocation [2]).

The majority of hypoprolific boars diagnosed as carriers of chromosomal rearrangements (19/21) were detected (as hypoprolific) directly and autonomously by the breeding organisations. About half of the hypoprolific boars detected in this way (and subsequently controlled in our laboratory) turned out to be carriers of chromosomal rearrangements. This ratio was much higher than that observed in the case of centralised detection (at the laboratory level) of boar hypoprolificacy (less than 1 carrier detected out of 20 hypoprolific boars). The reasons for this difference in efficiency of the two approaches have already been discussed in detail $[4,5,11]$ and will not be recalled here. Nevertheless, such results incite us to strongly advise the breeding organisations to systematically control any boars that they have detected as hypoprolific. This recommendation concerns purebred boars as well as terminal crossbred boars. 
Indeed, any boar carrying a structural chromosomal rearrangement (translocation, inversion) may have inherited it from one of its parents (which may be purebred animals). When hypoprolificacy of a boar is detected early on, the probability that its parents are still alive is high. Chromosomal control of the parents may in some cases then allow the same rearrangement to be detected in one of them, notably the dam in which it could have more easily remained unnoticed. This approach would reinforce the overall efficiency of the chromosomal control programme.

In conclusion, the interest and efficiency of the chromosomal control programme being carried out in France is already acknowledged by most French porcine breeding organisations, as well as other European companies. In view of the results presented in this paper, the implementation of comparable and complementary programmes in other European and North American countries seems relevant. In addition, the development of such diagnostic activities will supply scientists with unique biological material for use in fundamental cytogenetic studies. These could be aimed for instance at documenting the impact of structural chromosomal rearrangements on the course and products of meiosis, or on the structure and dynamics of chromosome territories in various cell types, including gametes. The development of such scientific projects in the pig, currently considered as a model species, should permit further progress more easily than in human cytogenetics, due to the easier access to biological material (e.g. embryos and gametes; see for instance paper by Pinton and collaborators [20] comparing male and female segregation profiles of reciprocal translocations). The results will also be more relevant to human cytogenetics than those from mouse cytogenetics, due to the greater similarity of karyotype structure between domestic pigs and humans.

\section{ACKNOWLEDGEMENTS}

We thank the pig selection organisations, artificial insemination centres and breeders for their assistance in animal rearing and sampling.

\section{REFERENCES}

[1] Anton E., Blanco J., Egozcue J., Vidal F., Sperm studies in heterozygote inversion carriers: a review, Cytogenet. Genome Res. 111 (2005) 297-304.

[2] Benet J., Oliver-Bonet M., Cifuentes P., Templado C., Navarro J., Segregation of chromosomes in sperm of reciprocal translocation carriers: a review, Cytogenet. Genome Res. 111 (2005) 281-290. 
[3] Debernardini S., Lillington D., Young B.D., Understanding cancer at the chromosome level: 40 years of progress, Eur. J. Cancer 40 (2004) 1960-1967.

[4] Ducos A., Berland H.M., Pinton A., Séguéla A., Darre R., Un reproducteur porcin de qualité doit être indemne d'anomalie chromosomique, Rev. Méd. Vét. 147 (1996) 101-108.

[5] Ducos A., Berland H.M., Pinton A., Séguéla A., Blanc M.F., Darré A., Sans P., Darré R., Les translocations réciproques chez le porc : état des lieux et perspectives, Journées Recherche Porcine 29 (1997) 375-382.

[6] Ducos A., Berland H.M., Pinton A., Guillemot E., Séguéla A., Darré A., Darré R., Nine new cases of reciprocal translocation in the domestic pig, J. Hered. 89 (1998) 136-142.

[7] Ducos A., Pinton A., Séguéla A., Berland H.M., Brun-Baronnat C., Bonnet N., Darré R., Contrôle chromosomique des populations porcines en France : bilan de 5 années d'activité, Journées Recherche Porcine 34 (2002) 269-275.

[8] Ducos A., Pinton A., Yerle M., Séguéla A., Berland H.M., Brun-Baronnat C., Darré R., Cytogenetic and molecular characterization of 8 new reciprocal translocations in the pig species. Estimation of their incidence in the French populations, Genet. Sel. Evol. 34 (2002) 389-406.

[9] Ducos A., Pinton A., Berland H.M., Calgaro A., Brun-Baronnat C., Bonnet N., Darré R., Milan D., Cleft palate associated with an unbalanced karyotype in piglets sired by a boar heterozygous carrier of a balanced constitutional reciprocal translocation, Vet. Record 154 (2004) 659-661.

[10] Gustavsson I., Chromosome aberrations and their influence on the reproductive performance of domestic animals - a review, Z. Tierz. Zuchtungsbiol. 97 (1980) 176-195.

[11] Legault C., Popescu C.P., Les translocations réciproques chez le porc domestique : détection, éradication et prévention, Elevage Insémination 254 (1993) $1-12$.

[12] Long S.E., Reciprocal translocations in the pig (Sus scrofa): a review, Vet. Record 128 (1991) 275-278.

[13] McKinlay-Gardner R.J., Sutherland G.R., Basic concepts: elements of medical genetics, in: McKinlay-Gardner R.J., Sutherland G.R. (Eds.), Chromosome abnormalities and genetic counselling, Oxford University Press, New York, 2004, pp. 3-19.

[14] Miyake Y.I., Matsubara T., Hata M., Kaneda Y., Chromosomal pericentric inversion detected in a sow and her piglets, Theriogenology 42 (1994) 241-246.

[15] Pinton A., Ducos A., Séguéla A., Berland H.M., Darré R., Darré A., Pinton P., Schmitz A., Cribiu E.P., Yerle M., Characterization of reciprocal translocations in pigs using dual-color chromosome painting and PRINS, Chromosome Res. 6 (1998) 361-365.

[16] Pinton A., Ducos A., Berland H.M., Séguéla A., Brun-Baronnat C., Darré A., Darré R., Yerle M., Chromosomal abnormalities in hypoprolific boars, Hereditas 132 (2000) 55-62.

[17] Pinton A., Pailhoux E., Piumi F., Rogel-Gaillard C., Yerle M., Ducos A., Cotinot C., A case of intersexuality in pigs associated with a de Novo paracentric inversion 9(p1.2;p2.2), Anim. Genet. 33 (2002) 69-71. 
[18] Pinton A., Ducos A., Yerle M., Chromosomal rearrangements in cattle and pigs revealed by chromosome microdissection and chromosome painting, Genet. Sel. Evol. 35 (2003) 685-696.

[19] Pinton A., Ducos A., Yerle M., Estimation of the proportion of genetically unbalanced spermatozoa in the semen of boars carrying chromosomal rearrangements using spermFISH, Genet. Sel. Evol. 36 (2004) 123-137.

[20] Pinton A., Faraut T., Yerle M., Gruand J., Pellestor F., Ducos A., Comparison of male and female meiotic segregation patterns in translocation heterozygotes: a case study in an animal model (Sus scrofa domestica L.), Hum. Reprod. 20 (2005) 2476-2482.

[21] Popescu C.P., Legault C., Anomalies chromosomiques et "hypoprolificité", Journées Recherche Porcine 20 (1988) 297-304.

[22] Popescu C.P., Tixier M., L'incidence des anomalies chromosomiques chez les animaux de ferme et leurs conséquences économiques, Ann. Génét. 27 (1984) 69-72.

[23] Popescu C.P., Bonneau M., Tixier M., Bahri I., Boscher J., Reciprocal translocations in pigs. Their detection and consequences on animal performances and economic losses, J. Hered. 75 (1984) 448-452.

[24] Roux C., Tripogney C., Morel F., Joanne C., Fellmann F., Clavequin M.C., Bresson J.L., Segregation of chromosomes in sperm of Robertsonian translocation carriers, Cytogenet. Genome Res. 111 (2005) 291-296.

[25] Tribout T., Ducos A., Maygnel L., Bidanel J.P., Utilisation du système d'information BLUP pour la détection des verrats porteurs d'anomalies chromosomiques, Techniporc 23 (2000) 19-24.

Appendix I. Exhaustive list of structural chromosomal rearrangements identified in the laboratory during the 2002-2006 period.

\begin{tabular}{|c|c|c|c|c|c|}
\hline Rearrangement* & Date & Control reason ${ }^{* *}$ & Breed*** & Sex & Origin of the animal \\
\hline $\mathrm{t}(12,14)(\mathrm{q} 13 ; \mathrm{q} 15)$ & Jan-02 & 1 & DU & $\mathrm{M}$ & France \\
\hline $\mathrm{t}(5,14)(\mathrm{q} 21 ; \mathrm{q} 12)$ & Mar-02 & 1 & DU & M & France \\
\hline $\mathrm{t}(17,18)(\mathrm{q} 21 ; \mathrm{q} 11)$ & Mar-02 & 2 & $\mathrm{P}$ & $\mathrm{M}$ & France \\
\hline $\mathrm{t}(5,9)(\mathrm{p} 11 ; \mathrm{p} 24)$ & May-02 & 2 & LF & M & France \\
\hline $\mathrm{t}(3 ; 16)(\mathrm{q} 23 ; \mathrm{q} 22)$ & May-02 & $1+$ cleft palate & $\mathrm{X}$ & M & France \\
\hline $\operatorname{inv}(8)(\mathrm{p} 11 ; \mathrm{q} 25)$ & Jun-02 & 2 & LW & M & France \\
\hline $\mathrm{t}(2 ; 8)(\mathrm{p} 11 ; \mathrm{p} 13)$ & Jun-02 & 3 & LW & $\mathrm{F}$ & France \\
\hline $\mathrm{t}(7 ; 12)(\mathrm{q} 11 ; \mathrm{p} 15)$ & Jul-02 & 2 & $\mathrm{P}$ & M & France \\
\hline $\operatorname{inv}(1)(\mathrm{p} 24 ; \mathrm{q} 29)$ & Sep-02 & 2 & LF & M & France \\
\hline $\mathrm{t}(7 ; 9)(\mathrm{q} 15 ; \mathrm{q} 15)$ & Sep-02 & 2 & LW & M & France \\
\hline $\mathrm{t}(17,18)(\mathrm{q} 21 ; \mathrm{q} 11)$ & Sep-02 & 2 & $\mathrm{P}$ & M & France \\
\hline $\mathrm{t}(6 ; 13)(\mathrm{p} 13 ; \mathrm{q} 49)$ & Oct-02 & 2 & LW & M & France \\
\hline $\operatorname{inv}(2)(\mathrm{p} 11 ; \mathrm{q} 21)$ & Oct-02 & 2 & $\mathrm{P}$ & M & France \\
\hline $\mathrm{t}(5 ; 9)(\mathrm{q} 21 ; \mathrm{p} 13)$ & Nov-02 & 2 & LF & M & France \\
\hline $\mathrm{t}(4 ; 5)(\mathrm{p} 13 ; \mathrm{q} 21)$ & Nov-02 & 1 & $\mathrm{X}$ & $\mathrm{M}$ & France \\
\hline $\mathrm{t}(2 ; 8)(\mathrm{p} 11 ; \mathrm{p} 13)$ & Nov-02 & 2 & LW & M & France \\
\hline
\end{tabular}


Appendix I. Continued.

\begin{tabular}{|c|c|c|c|c|c|}
\hline Rearrangement* & Date & Control reason $* *$ & Breed $^{* * *}$ & Sex & Origin of the animal \\
\hline $\mathrm{t}(12 ; 14)(\mathrm{q} 15 ; \mathrm{q} 13)$ & Jan-03 & 2 & $\mathrm{P}$ & $\mathrm{M}$ & France \\
\hline $\mathrm{t}(9 ; 17)(\mathrm{p} 24 ; \mathrm{q} 23)$ & Jan-03 & 2 & $\mathrm{X}$ & $\mathrm{M}$ & France \\
\hline $\mathrm{t}(14 ; 16)(\mathrm{q} 13 ; \mathrm{q} 21)$ & Feb-03 & 2 & $\mathrm{P}$ & M & France \\
\hline $\mathrm{t}(4 ; 12)(\mathrm{q} 21 ; \mathrm{q} 13)$ & Mar-03 & research protocol & $X$ & M & France \\
\hline $\mathrm{t}(7 ; 9)(\mathrm{q} 11 ; \mathrm{q} 26)$ & Apr-03 & 2 & LW & M & France \\
\hline $\mathrm{t}(13 ; 16)(\mathrm{q} 41 ; \mathrm{q} 21)$ & May-03 & 1 & np & M & The Netherlands \\
\hline $\mathrm{t}(1 ; 13)(\mathrm{q} 27 ; \mathrm{q} 41)$ & Jun-03 & 1 & DU & M & The Netherlands \\
\hline $\mathrm{t}(7 ; 14)(\mathrm{q} 26 ; \mathrm{q} 25)$ & Jul-03 & 1 & np & M & The Netherlands \\
\hline $\mathrm{t}(7 ; 10)(\mathrm{q} 13 ; \mathrm{q} 11)$ & Oct-03 & 1 & np & M & The Netherlands \\
\hline $\mathrm{t}(9 ; 14)(\mathrm{p} 24 ; \mathrm{q} 15)$ & Jan-04 & 2 & $\mathrm{LS}$ & $\mathrm{M}$ & France \\
\hline $\mathrm{t}(13 ; 15)(\mathrm{q} 31 ; \mathrm{q} 26)$ & Feb-04 & 2 & $\mathrm{P}$ & $\mathrm{M}$ & France \\
\hline $\operatorname{inv}(8)(p 21 ; q 11)$ & Feb-04 & 2 & $\mathrm{P}$ & M & France \\
\hline $\mathrm{t}(1 ; 11)(\mathrm{q} 11 ; \mathrm{q} 11)$ & Mar-04 & 2 & $\mathrm{P}$ & M & France \\
\hline $\mathrm{t}(4 ; 13)(\mathrm{p} 15 ; \mathrm{q} 41)$ & Apr-04 & 1 & np & M & The Netherlands \\
\hline $\mathrm{t}(1 ; 17)(\mathrm{p} 11 ; \mathrm{q} 11)$ & May-04 & 1 & $\mathrm{P}$ & M & The Netherlands \\
\hline $\mathrm{t}(8 ; 12)(\mathrm{p} 11 ; \mathrm{p} 11)$ & May-04 & 1 & np & M & The Netherlands \\
\hline $\mathrm{t}(11 ; 17)(\mathrm{p} 13 ; \mathrm{q} 21)$ & May-04 & 3 & SE & $\mathrm{F}$ & France \\
\hline $\mathrm{t}(10 ; 13)(\mathrm{q} 13 ; \mathrm{q} 22)$ & Jun-04 & 1 & LS & M & The Netherlands \\
\hline $\mathrm{t}(5 ; 7)(\mathrm{q} 23 ; \mathrm{p} 11)$ & Oct-04 & 3 & SE & $\mathrm{F}$ & France \\
\hline $\mathrm{t}(2 ; 9)(\mathrm{q} 13 ; \mathrm{q} 24)$ & Oct-04 & 2 & LW & M & France \\
\hline $\operatorname{inv}(6)(p 14 ; q 12)$ & Oct-04 & 3 & SE & $\mathrm{F}$ & France \\
\hline $\mathrm{t}(14 ; 15)(\mathrm{q} 28 ; \mathrm{q} 13)$ & Nov-04 & 3 & SE & $\mathrm{F}$ & France \\
\hline $\mathrm{t}(2 ; 16)(\mathrm{q} 28 ; \mathrm{q} 21)$ & Jan-05 & 2 & SE & $\mathrm{M}$ & France \\
\hline $\mathrm{t}(4 ; 15)(\mathrm{q} 25 ; \mathrm{q} 11)$ & Mar-05 & 2 & LF & M & France \\
\hline $\mathrm{t}(10 ; 17)(\mathrm{q} 11 ; \mathrm{q} 21)$ & May-05 & 1 & np & M & The Netherlands \\
\hline $\mathrm{t}(1 ; 15)(\mathrm{q} 17 ; \mathrm{q} 22)$ & Jun-05 & 1 & LS & M & The Netherlands \\
\hline $\mathrm{t}(7 ; 14)(\mathrm{q} 15 ; \mathrm{q} 27)$ & Jun-05 & 1 & $X$ & M & France \\
\hline $\begin{array}{c}\mathrm{t}(10 ; 18)(\mathrm{p} 11 ; \mathrm{q} 24)+ \\
\mathrm{t}(6 ; 8)(\mathrm{p} 15 ; \mathrm{q} 27) \\
\operatorname{der}(14 ; 15)(\mathrm{q} 10 ; \mathrm{q} 10)=\end{array}$ & Aug-05 & 2 & $\mathrm{P}$ & M & France \\
\hline $\operatorname{rob}(14 ; 15)$ & Aug-05 & 2 & $\mathrm{LF}$ & M & France \\
\hline $\mathrm{t}(4 ; 16)(\mathrm{q} 25 ; \mathrm{q} 21)$ & Sep-05 & 1 & LS & M & The Netherlands \\
\hline $\operatorname{inv}(1)(q 18 ; q 24)$ & Oct-05 & 2 & LW & M & France \\
\hline $\begin{array}{l}\operatorname{inv}(2)(p 13 ; q 12)+ \\
t(13: 14)(q 31: q 21)\end{array}$ & & & & & \\
\hline $\begin{array}{c}\mathrm{t}(13 ; 14)(\mathrm{q} 31 ; \mathrm{q} 21) \\
\mathrm{t}(10 ; 11)(\mathrm{q} 16 ; \mathrm{q} 13)\end{array}$ & $\begin{array}{l}\text { Oct-05 } \\
\text { Dec-05 }\end{array}$ & $\begin{array}{l}2 \\
2\end{array}$ & $\begin{array}{c}\text { LS } \\
\text { P }\end{array}$ & $\begin{array}{l}\mathrm{M} \\
\mathrm{M}\end{array}$ & $\begin{array}{l}\text { France } \\
\text { France }\end{array}$ \\
\hline $\mathrm{t}(2 ; 17)(\mathrm{p} 12 ; \mathrm{q} 14)$ & Dec-05 & 3 & DU & $\mathrm{F}$ & France \\
\hline $\mathrm{t}(10 ; 17)(\mathrm{q} 11 ; \mathrm{q} 21)$ & Jan-06 & 2 & LW & $\mathrm{M}$ & The Netherlands \\
\hline $\mathrm{t}(3 ; 8)(\mathrm{q} 25 ; \mathrm{p} 21)$ & Jan-06 & np & LS & M & France \\
\hline $\mathrm{t}(2 ; 14)(\mathrm{p} 15 ; \mathrm{q} 26)$ & Jan-06 & 3 & $X$ & $\mathrm{~F}$ & France \\
\hline $\operatorname{inv}(2)(q 13 ; q 25)$ & Jan-06 & 2 & DU & M & The Netherlands \\
\hline $\mathrm{t}(\mathrm{Y} ; 14)(\mathrm{q} 10 ; \mathrm{q} 11)$ & Jan-06 & 2 & DU & M & France \\
\hline $\mathrm{t}(1 ; 11)(\mathrm{q} 24 ; \mathrm{p} 13)$ & Feb-06 & 1 & $\mathrm{np}$ & M & Spain \\
\hline $\mathrm{t}(14 ; 15)(\mathrm{q} 28 ; \mathrm{q} 13)$ & Feb-06 & 1 & np & M & Germany \\
\hline $\mathrm{t}(2 ; 15)(\mathrm{q} 28 ; \mathrm{q} 24)$ & Feb-06 & 1 & $\mathrm{np}$ & M & Germany \\
\hline
\end{tabular}


Appendix I. Continued.

\begin{tabular}{lccccc}
\hline Rearrangement* & Date & Control reason** & Breed*** & Sex & Origin of the animal \\
\hline $\mathrm{t}(9 ; 11)(\mathrm{q} 14 ; \mathrm{p} 13)$ & May-06 & 3 & $\mathrm{MS}$ & $\mathrm{F}$ & France \\
$\mathrm{t}(1 ; 7)(\mathrm{q} 17 ; \mathrm{q} 13)$ & Jul-06 & 1 & $\mathrm{np}$ & $\mathrm{M}$ & The Netherlands \\
$\mathrm{t}(2 ; 14)(\mathrm{q} 21 ; \mathrm{q} 24)$ & Jul-06 & 1 & $\mathrm{np}$ & $\mathrm{M}$ & The Netherlands \\
$\operatorname{der}(14 ; 17)(\mathrm{q} 10 ; \mathrm{q} 10)=$ & & & & & \\
$\quad$ rob(14;17) & Sep-06 & 2 & $\mathrm{np}$ & $\mathrm{M}$ & The Netherlands \\
$\mathrm{t}(1 ; 4)(\mathrm{q} 27 ; \mathrm{q} 21)$ & Oct-06 & 2 & $\mathrm{P}$ & $\mathrm{M}$ & Germany \\
$\operatorname{der}(13 ; 17)(\mathrm{q} 10 ; \mathrm{q} 10)$ & & & & & \\
$\operatorname{rob}(13 ; 17)$ & Nov-06 & 2 & LF & $\mathrm{M}$ & France \\
$\mathrm{t}(3 ; 11)(\mathrm{q} 13 ; \mathrm{p} 11)$ & Nov-06 & 2 & LS & $\mathrm{M}$ & France \\
\hline
\end{tabular}

$*: \mathrm{t}=$ Reciprocal translocation; inv = inversion; rob = Robertsonian translocation.

**: 1 = Hypoprolific boar; 2 = young boar controlled before service; 3 = female; np $=$ not indicated.

***: LW = Large White; LF = French Landrace; $\mathrm{P}=$ Piétrain; LS = Synthetic Line; $\mathrm{DU}=$ Duroc $; \mathrm{MS}=$ Meishan $; \mathrm{SE}=$ sino European $\mathrm{X}=$ crossbred $; \mathrm{np}=$ not indicated. 